\title{
SUPPLY-SIDE PERFORMANCE IN THE CZECH REPUBLIC: A MACROECONOMIC VIEW (1995-2005)
}

\author{
Jaromír Hurník, Dana Hájková *
}

\begin{abstract}
:
In this paper, we apply the aggregate production function to approximate the path of potential output and decompose it into its determinants. Based on the decomposition we evaluate the supply side performance from a macroeconomic perspective. We use a time-varying NAIRU to derive the amount of potential labour and a newly developed measure of capital services to account for the productive impact of capital. In addition, trend total factor productivity is estimated. During 1995-2000, the growth in potential output was constrained by a gradual increase in the NAIRU, a temporary drop in investment activity and, most importantly, by only a modest rise in total factor productivity. For the period 2001-2005, we observe substantial improvements in the supply-side performance, except for the functioning of the labour market.
\end{abstract}

Keywords: capital services, growth accounting, NAIRU, potential output, production function, total factor productivity

JEL Classification: E23, O11, 012, O47

\section{Introduction}

A natural starting point for evaluating aggregate supply-side functioning is to look at developments at the macro level, where the rate of growth of potential output is the usual expression of supply-side performance. When assessing the supply-side performance, however, it is not the rate of the potential output growth per se that is of primary importance, but rather the decomposition of the potential output into its determinants.

From the point of view of production factors, besides inflows of labour and capital, the rate of potential output growth is conventionally attributed to the trend in total factor productivity. When assessing the nature of aggregate supply-side functioning in the longer run, it is then central to distinguish between changes in aggregate productive capaci-

* Jaromír Hurník, Czech National Bank, and Faculty of Economics and Public Administration, University of Economics, Prague, and Institute of Economic Studies, FSV, Charles University, Prague (jaromir.hurnik@cnb.cz); Dana Hájková, Czech National Bank, and CERGE-EI (dana.hajkova@cnb.cz).

This work was supported by Czech National Bank Research Project No. D1/2002 and it was published as a part of Czech National Bank WP No. 4/2006. The authors wish to thank Jan Frait, Mojmír Hájek, Pete Richardson, Vilém Valenta and three anonymous referees for helpful comments. The views expressed are those of the authors and do not necessarily reflect the views of the Czech National Bank. 
ty due to a varying amount of factor inputs (labour and capital) and due to improvements in the productive use of inputs (total factor productivity, TFP).

Next to the backward looking evaluation of the production efficiency, the decomposition of potential output into its determinants may also provide a useful insight for future development and possibly signalize risks stemming from the actual development of production factors. For instance, increasing equilibrium unemployment indicates worsening labour market efficiency. This in turn reduces growth in "potential employment" and, finally, diminishes potential output growth. Similarly, low TFP growth would indicate a low intensity of technological and other innovations, again with a limiting impact on potential output growth.

Our point is that low TFP, possibly observable at the macro level, could be caused by inefficient allocation of factor inputs. Low supply-side flexibility makes the economy operate at aggregate growth rates that are lower than otherwise sustainable, thus adversely affecting the path of potential output growth.

In this paper we identify the main factors behind the development of potential output in the Czech Republic during 1995-2005 using the production function approach, and from this viewpoint evaluate the supply-side functioning. There are two methodological advances employed in this analysis that are worth mentioning. First, following our previous research, we incorporate the concept of a time-varying NAIRU into the production function approach, to derive "potential labour". Second, we use the concept of "capital services" to capture the real productive impact of capital factor input.

The rest of this paper is organised as follows: In Section 2 we discuss the methodology applied, Section 3 describes the data. In Section 4 we discuss our results and in Section 5 we present a sensitivity analysis. Section 6 concludes.

\section{Production Function}

Following Giorno et al. (1995), we assume the standard neo-classical two factor Cobb-Douglas production function with Hicks-neutral technology:

$$
Y_{t}=A_{t} \cdot L_{t}^{\alpha} \cdot K_{t}^{\beta}
$$

where $Y, L, K$ and $A$ are real GDP, labour input, capital input and the TFP level respectively. This specification is a special case of the constant-elasticity-of-substitution production function (CES), with an elasticity of substitution equal to one. There are some usual theoretical assumptions about this production function specification used in the empirical literature. ${ }^{1}$

First, positive and diminishing marginal products with respect to each input $(L, K)$ are assumed. This restricts both $\alpha$ and $\beta$ to values between 0 and 1 . Second, an often adopted assumption on returns to scale is that they are constant, i.e. $\beta=(1-\alpha)$. However, this assumption is not obvious in reality and the use of increasing returns has been suggested instead when using endogenous growth models (see, for example, Barro, 1998). Increasing returns for the whole economy would then reflect the existence of a specific

1 See, for example, Romer (1990), Grossman and Helpman (1991), Barro and Sala-i-Martin (1995), Giorno et al. (1995), Barro (1998) or Scacciavillani and Swagel (1999) for a more detailed discussion as well as criticism of the standard assumptions used in modelling the production function. 
research and development sector that would be able to produce positive spillovers for the rest of the economy. The research and development sector would operate under strongly increasing returns to scale whereas the rest of the economy would operate under constant returns to scale.

Hurník and Navrátil (2005b), however, do not find any significant evidence for the existence of such a specific sector in the Czech economy, so they apply the assumption of constant returns to scale. Here we simply follow the same approach. Given the assumption about perfectly competitive markets, constant returns to scale and no unobserved inputs, $\alpha$ then corresponds to the income share of labour. ${ }^{2}$

If the factor markets are competitive, then the marginal product of each input equals its factor price, so $\partial Y_{t} / \partial L_{t}=w_{t}$ and $\partial Y_{t} / \partial \mathrm{K}_{t}=R_{t}$, where $w_{t}$ and $R_{t}$ are the wage rate and the rental rate of capital respectively. Differentiation of the production function (2.1) with respect to $L$ yields $\frac{\partial Y_{t}}{\partial L_{t}}=\alpha \frac{Y_{t}}{L_{t}}$, hence $\alpha=\frac{w_{t} L_{t}}{Y_{t}}$.

By choosing the Cobb-Douglas specification of the production function, Giorno et al. (1995) assume the labour share, which serves for the quantification of $\alpha$ (and, hence, $\beta$ ), to be constant over time. ${ }^{3}$ Our estimation of potential output therefore assumes the labour share to be constant over time and the observed fluctuations of $\frac{w_{t} L_{t}}{Y_{t}}$ to reflect errors of measurement.

It can be easily argued, however, that this assumption is perhaps not fully appropriate for the Czech economy, which has not yet reached its steady state (in which GDP per capita grows at the rate of technological progress and the shares of capital and labour are constant), since the process of economic convergence has not finished. One can observe that the labour share has been increasing in the Czech Republic in the period 1995-2005.

Relaxing the assumption of constant labour share would exclude the Cobb-Douglas production function from use (Barro 1995, p. 347). Hájková and Hurník (2007) analyse the impact of relaxing the assumptions described above using a general form of production function. They obtain similar results for the growth rates of TFP and potential product in a growth accounting exercise using both Cobb-Douglas production function and general production function with time-varying labour share. We are, therefore, rather confident to follow the assumption of constant labour share like Giorno et al. (1995).

The measurement of labour share is discussed, for instance, in Krueger (1999) and Gomme and Rupert (2004). In the classical sense, where perfectly competitive markets and constant returns to scale are assumed, $\alpha$ and $\beta$ would be the respective shares of each factor remuneration in total factor income (assumed to be equal to total nominal output). Since neither of these factor remunerations is explicitly measured, for this purpose, the total income (or, more precisely, the mixed income ${ }^{4}$ ) is apportioned according to some method to capital and labour. Usually, this involves assuming some rate of return for one

2 Schreyer (2004) analyses the consequences when these assumptions are not fulfilled.

3 In cross-country comparisons, some researchers use a generally accepted calibrated value close to 0.3 for the capital share - see, for example, Bosworth and Collins (2003).

4 The gross operating surplus cannot be fully attributed to fixed capital. It is a measure of business profits from normal operating activity and includes the so-called mixed income, i.e., income of self-employed persons. 
or both of these factors that is endogenous to the method chosen and does not have to correspond to ex-ante beliefs about their true values. We calculate $\alpha_{t}$ by (2.2), where $t c_{t}$ represents total nominal labour cost per employee, $L_{t}$ stands for total employment (including self-employment and adjusted for hours worked) and $g v a_{t}$ is the economy's gross value added at current prices (i.e. GDP net of indirect taxes and subsidies). This method assumes that the average remuneration in dependent employment and self-employment are alike.

$$
\alpha_{t}=\frac{t l c_{t} \cdot L_{t}}{g v a_{t}}
$$

The value of $\alpha$ used in the following exercise is computed as the average over the whole period of the yearly labour shares $\alpha_{t}$. Parameter $\beta$ then simply equals $(1-\alpha)$.

The TFP level (see variable $A$ in equation 2.1) cannot be measured directly. We can estimate the so-called gross total factor productivity, which consists of two parts: (i) the trend total factor productivity $\left(A^{*}\right)$; and (ii) a short-term fluctuation, which is assumed to correspond to the business cycle. Rewriting equation 2.1, the level of gross TFP for each period is given by 2.3 (regardless of the sustainability of its amount in the long term):

$$
A_{t}=\left[\frac{Y_{t}}{L_{t}^{\alpha} \cdot K_{t}^{1-\alpha}}\right]
$$

where $Y$ is real GDP, $L$ is the labour input measured by total employment adjusted for hours worked and $K$ is the capital input measured by capital services. Then, the long-run trend of the total factor productivity $\left(A^{*}\right)$ is approximated by finding the trend of $A$ and deviations from this trend are assumed to be short-term fluctuations. ${ }^{5}$ In Section 4, estimated values of $A^{*}$ are presented in Figure 4.1. and Table 4.1. One must admit that the results are sensitive to the smoothing techniques used to detrend gross total factor productivity. For our trend estimation, we employ (instead of the commonly used Hodrick-Prescott filter) the band-pass filter suggested by Baxter and King (1995) and Christiano and Fitzgerald (1999) ${ }^{6}$. Among others, Christiano and Fitzgerald (1999) prove that the band-pass filter outperforms the Hodrick-Prescott filter regarding end-point bias ${ }^{7}$. In our exercise we remove any frequency lower than 32 quarters from the calculated gross total factor productivity.

5 The variations in the measure of TFP include not only pure changes in technology, but also other factors of improving aggregate productivity, such as improvements in allocative efficiency as well as the existence of mark-ups or technological spillovers (see also Section 6 for a discussion).

6 The band-pass filter can be used to isolate the component of a time series that lies within a particular band of frequencies. It relies on the Spectral Representation Theorem, according to which any time series within a broad class can be decomposed into different frequency components. See Baxter and King (1995) and Christiano and Fitzgerald (1999) for an extensive discussion.

7 „No claim has ever been made that the HP filter is an optimal approximation to this band pass filter in any sense. This is consistent with our findings ... which show that the Random Walk and Optimal filters dominate HP, especially for computing real-time estimates of $x_{t}$ " " (Christiano and Fitzgerald, 1999, p. 27). 
Potential output is calculated using the trend total factor productivity $\left(A^{*}\right)$, as described above, in combination with the estimated potential employment $\left(L^{*}\right)$ and the measure of capital services $(K)$. Potential employment is the level of employment which can be sustained without inducing additional inflationary pressures:

$$
L^{*}=\hat{L} \cdot(1-N A I R U)
$$

where $\hat{L}$ represents the labour force ${ }^{8}$ and the term NAIRU stands for the non-accelerating inflation rate of unemployment. To derive the NAIRU, we use the model developed for the Czech economy by Hurník and Navrátil (2005a). ${ }^{9}$ This model for estimating the NAIRU starts with the following inflation equation:

$p_{t}^{\text {core }}=\alpha_{1} \cdot E_{t} p_{t+1}^{\text {core }}+\alpha_{2} \cdot p_{t-1}^{\text {core }}+\left(1-\alpha_{1}-\alpha_{2}\right) \cdot p_{t}^{\text {imp }}+\beta\left(u_{t-1}-u_{t-1} *\right)+\gamma \cdot z_{t-1}+e_{t}$,

where $p_{t}^{\text {core }}, p_{t}^{\text {imp }}, u_{t}, u_{t}^{*}$ and $z_{t}$ denote quarterly annualised core inflation, quarterly annualised import price inflation, the actual unemployment rate, the time varying NAIRU and the real effective exchange rate respectively.

Based on the use of the Gaussian maximum likelihood method, the model combines inflation equation (2.5) with equation (2.6), which describes the explicit path of the NAIRU:

$$
\begin{gathered}
u_{t}^{*}=u_{t-1}{ }^{*}+\varepsilon_{\tau} \\
e_{t} \sim N\left(0, \sigma_{e}^{2}\right) ; \varepsilon_{t} \sim N\left(0, \sigma_{\varepsilon}^{2}\right) \\
\operatorname{cov}\left(e_{j}, \varepsilon_{k}\right)=0
\end{gathered}
$$

The error term $\varepsilon_{t}$ in the "state" equation (2.6) is expected to be white noise with standard deviation $\sigma_{\varepsilon}$. If $\sigma_{\varepsilon}=0$, the NAIRU is constrained to be constant and the estimation is quite simple. But if $\sigma_{\varepsilon} \neq 0$, the NAIRU is changing over time and the estimation is more complicated. Specification (2.6) implies that the NAIRU follows a random walk and that changes in the NAIRU are driven by $\sigma_{\varepsilon}$. The disturbance vectors $e_{t}$ and $\varepsilon_{t}$ are assumed to be uncorrelated with each other in all time periods. ${ }^{10}$ Figure 4.2 in Section 4 presents the estimated NAIRU along with observed unemployment rate.

8 The labour force is represented by the economically active population, i.e. all persons aged 15 years or over who are classified as employed or unemployed according to the ILO methodology (see CZSO, 2005b).

9 See this source for a detailed description of the model applied to estimate the time-varying NAIRU.

10 Equation (2.6) strictly follows the necessary form for an unobserved (state) variable used in the state-space form of the model (equations (2.5) and (2.6)). Based on the state-space form, the Kalman filter is constructed, the log-likelihood function computed, and the maximum likelihood estimator used for estimation of model parameters. In general, the Kalman filter provides estimates of the unobserved variable, while estimates of any other desired parameters are obtained by maximum likelihood estimator. For an extensive theoretical discussion of this technique see Hamilton (1994) and Hurník and Navrátil (2005a) for references to practical applications. 
Finally, we have to explain our approach to incorporating the capital input into the production function model. A standardly used measure accounting for capital input in the Czech Republic has been the change in the net capital stock (used most recently in Hurník and Navrátil, 2005b, and Hájek, 2006). There are, however, several problems connected with the ability of this measure to capture the productive capital input (OECD, 2001).

First, the factors of production should be measured as flows. Second, conventional measures of the net capital stock do not reflect the productive efficiency of capital assets (evaluating assets in market prices will most likely underestimate the productive efficiency, as prices usually decline quite rapidly in the early years of the service life). And finally, these measures weight each asset by its market value in aggregation, which basically implies that two assets with the same value have the same contribution to production. Thus, expensive assets with a long service life are assumed to have a relatively larger contribution to production than cheaper assets with a short life.

In order to eliminate the above-mentioned drawbacks, the capital input is measured by the volume of capital services derived from the existing productive capital stock. We use the experimental measure described in Hájková (2006) that better accounts for the heterogeneity and productive efficiency of capital assets.

Capital services are viewed as a flow of productive services from the cumulative stock of past investments. According to Schreyer et al. (2003), the quantity of productive services $K_{t}^{i}$ in year $t$ of a capital asset of type $i$ is assumed to be a function of past volumes of vintage investment to this asset, adjusted for the retirement pattern. It is shown that the value of capital services from i-type assets $u k_{t}^{i} K_{t}^{i}$ (i.e. the product of the price, $u k_{t}^{i}$, and the quantity, $K_{t}^{i}$, of capital services deriving from i-type asset) is equal to the product of the productive stock of these assets, $S_{t-1}^{i}$ expressed in "new equivalent" units, and its user $\operatorname{cost} u_{t}^{i}:{ }^{11}$

$$
u k_{t}^{i} K_{t}^{i}=u_{t}^{i} S_{t-1}^{i} .
$$

This identity, along with the fact that the cost of using one unit of vintage investment is proportional to the price of its capital service,

$$
u_{t}^{i}=\lambda^{i} u k_{t}^{i}
$$

can be used in quantifying the flow of capital services. The change in the volume of capital services flowing from an asset $i$ is then measured by the index of the productive stock of this asset. An important difference between the measures of capital stock and capital services consists in aggregation across assets. In order to construct the aggregate measure, it is necessary to keep in mind that each type of asset produces a specific flow of capital services in proportion to its productive stock and that this proportion differs across assets.

11 The productive stock $S_{t-1}^{i}$ of an $i$-type asset at the end of period $t-1$ can be computed by the perpetual inventory method as the sum of all vintage investment ( $s$ years ago) in this type of asset, $I_{t-\mathrm{s}-1}^{i}$, expressed in base-year prices, corrected for the probability of retirement and for the loss of productive capacity. 
The change in the volume of capital services is then given by:

$$
\ln \frac{K_{t}}{K_{t-1}}=\sum_{i} w_{t}^{i} \ln \frac{S_{t-1}^{i}}{S_{t-2}^{i}}
$$

The weights for aggregations, $w_{t}^{i}$, reflect the marginal productivity of different assets. Market prices of capital assets are not suitable weights because they reflect the flow of capital services of the assets over their expected remaining service life, but not for a single year. By contrast, the user cost, in equilibrium, equals the marginal revenue of an asset and is, hence, the correct weight. The user cost of an asset $i$ at time $t$ is defined as follows:

$$
u_{t}^{i}=q_{t-1}^{i}\left(r+d_{t}^{i}-\varsigma_{t}^{i}+d_{t}^{i} \varsigma_{t}^{i}\right),
$$

where $q_{t-1}^{i}$ is the purchase price of the asset, $r$ is the nominal discount rate, $d_{t}^{i}$ is the depreciation rate and $\varsigma_{t}^{i}$ is the rate of asset price change.

The Thörnqvist index ${ }^{12}$ of the share of each industry in total capital income then represents the weight that is assigned to the growth in the net stock of fixed assets at constant prices in this industry.

$$
w_{t}^{i}=\frac{1}{2}\left(\frac{u_{t}^{i} S_{t-2}^{i}}{u_{t} S_{t-2}}+\frac{u_{t+1}^{i} S_{t-1}^{i}}{u_{t+1} S_{t-1}}\right)
$$

The sum of the contributions derived from each capital asset represents the growth of the capital input (capital services) in a given year. Hence, we are able to construct a volume index of capital services for the period 1996-2003.

When we consider our measure of capital services for $K$, the trend total factor productivity $A^{*}$ and potential employment $L^{*}$, we obtain the following equation, which captures the determinants of potential output:

$$
Y_{t}^{*}=A_{t}^{*} \cdot L_{t}^{\alpha} * \cdot K_{t}^{\beta}
$$

\section{Data}

The period covered in this analysis starts with the first quarter of 1995 . This comes as an outcome of the availability of time series of real GDP and gross value added data that are consistent in terms of source and methodology. The end of our sample is the fourth quarter of 2005. All data are seasonally adjusted ${ }^{13}$.

Total labour costs per employee are published by the Czech Statistical Office (CZSO, 2005a) for the period 1994-2004. Total labour costs per employee for the year 2005 are then approximated using the information on the average wage (CZSO, 2006) and the ratio of 1.44 between the average wage and total labour costs observed in 2004.

12 See Thörnqvist (1936).

13 The data were seasonally adjusted from the original non-adjusted series using the Tramo-Seats methodology. 
Labour force data are published quarterly for the period 1994-2004 - see CZSO (2005b). Quarterly labour force data for 2005 are then based on CZSO (2006). Finally, the data on gross value added and GDP over the period 1995-2005 are available with quarterly periodicity from CZSO (2006).

The gross TFP is computed according to (2.3), with the use of real GDP, potential labour, capital services and the labour share. The measure of potential labour $L^{*}$, as defined by (2.4), is based on seasonally adjusted labour force data and estimates of the NAIRU. ${ }^{14}$

Capital input $K$ is measured by the volume of capital services, as described by equation (2.9). The length of time series of publicly available Czech data is insufficient to derive the volume of capital services precisely according to the methodology described by Schreyer et al. (2003). It can, however, be assumed that the measure of the net stock of capital at replacement cost, as computed by the Czech Statistical Office (CZSO), accounts for most of the age and obsolescence of assets and hence the loss of productive capacity. That is why it can be used as a good approximation of the productive stock of capital. It is therefore not computed, and the corresponding measure of the net stock of capital at constant replacement cost published in industry breakdown is used instead.

Consistent time series (in terms of source and methodology) of the net stock of fixed assets (replacement costs; end-year data), gross fixed capital formation and capital consumption in a breakdown by 60 industries are available for the period 1995-2002 in CZSO (2004). Data on gross fixed capital formation broken down into 16 NACE industries are available for the period 1995-2004. The weights for aggregation, the user costs, are constructed according to (2.8). To establish the required nominal rate of return at time $t$, we take into account the financing structure of firms and the effects of taxation. ${ }^{15}$

The depreciation rates in each industry, $d_{i}$, are computed as averages of the realised depreciation rates in the period 1996-2002. ${ }^{16}$ The expected price change of capital is computed as the three-year centred average of the deflator of gross fixed capital formation. ${ }^{17}$ The capital income in each industry is then computed for each year as product of the average net stock of fixed assets at current replacement cost and the required rate of return. Because of the availability of additional information, in particular gross fixed capital formation for the years 1995 (in detail for 60 industries) and 2003-2004 (in detail

14 For the NAIRU estimation, unemployment and labour force data from CZSO (2005b) and CZSO (2006) were used. Core inflation, import prices and the real exchange rate come from the CNB internal data base and can be obtained from the authors on request.

15 The constant required real rate of return (the opportunity cost of financial capital invested in an asset) is computed by deflating (using CPI inflation) the weighted average of the yields on a 10-year interest rate swap and the yield on corporate bonds adjusted for the tax shield, and averaged over the period of availability (1997-2005). The corresponding weights are 0.4 and 0.6 respectively and approximately reflect the prevailing financial structure of Czech corporations. The required nominal rate of return is then obtained by adding an expected inflation component (the three-year centred average of observed inflation). The data for 1997-2005 for 10-year interest rate swaps come from the CNB internal data base and can be obtained from the authors on request. The yield on corporate bonds is the Patria PRI index downloaded from Bloomberg.

16 The depreciation rate in each industry and year is computed as the ratio of the consumption of fixed capital and the average net stock of fixed capital in the respective year, both at current prices.

17 The purchase prices of assets are implicitly contained in the measure of the net capital stock at current replacement prices (all data from CZSO, 2004). 
for 16 industries), it is possible, with some reasonable assumptions, to approximate the development of capital services in the years 1995 and 2004-2005.

Based on the capital services growth rates calculated according to (2.9), we construct the values of capital services in 1995 prices. We depart from the year 1996 and use the fact that the value of capital services is equal to the price paid for them, i.e. the user cost of the prevailing productive stock of capital (cf. equation 2.7). These are expressed in 1995 prices and thus we can apply the real growth rates computed above to obtain the time series. However, it has to be kept in mind that these time series are in fact index numbers and, in particular, the levels are not additive across industries, with the exception of the base year. Finally, for the analysis at the aggregate level, we interpolate the annual values by fitting a local quadratic polynomial so that the sum of the quarterly values matches the annual data actually observed. ${ }^{18}$

\section{Results}

The income share of labour $(\alpha)$ for the period 1995-2005 is computed as the average over the whole period of the yearly labour shares defined by (2.2) and its value is $0.57 .{ }^{19}$ The robustness of the average value used is supported by the labour share standard deviation of 0.02 .

Figure 4.1 shows the results of calculating the trend total factor productivity $\left(A^{*}\right)$. Relatively remarkable and stable annual growth of the trend total factor productivity took place only from mid-2000 onwards. Based on this observation, one could interpret that the role of the trend total factor productivity for potential output growth was negligible in the second half of the $1990 \mathrm{~s} .{ }^{20}$ We analyse this development and discuss the underlying factors of low growth of the trend total factor productivity in more detail later in this section.

18 For the sake of space, the details are not presented here, but are available from the authors on request.

19 European Commission (Denis et al., 2006) uses a labour share of 0.63 in their potential growth model. Hájek (2006) reports labour share 0.62 for the year 2002.

20 Our results for the second half of the 1990s correspond to those of Flek et al. (2001) and Hájek (2006). It is worth mentioning that Hájek (2006) comes to the conclusion that the growth of the trend total factor productivity reached $0.7 \%$ in the period $1992-1998$ and $2.2 \%$ in the period 1999-2004. Although quantitatively similar, the results of Hájek (2006) are, however, not directly comparable, since Hájek (2006) employs the growth accounting approach that differs in several aspects from the methodology applied here. First it does not work explicitly with the concept of potential labour and NAIRU. Second, it does not split the gross total factor productivity into the trend total factor productivity and the short-term fluctuations. It seems therefore that the results of Hájek (2006) may be influenced by business cycle fluctuations significantly. In contrast, given the methodology of growth accounting the results of Hájek (2006) are not based on the assumption of constant labour share and Thörnqvist index is used instead. Finally, Hájek (2006) employs the measure of capital stock to account for the productive contribution of capital. 
Figure 4.1

Trend Total Factor Productivity $\left(A^{*}\right)$ (1995QI-2005Q4)

Levels (basic index, 1995Q1=100)

Growth (year-on-year growth in \%)
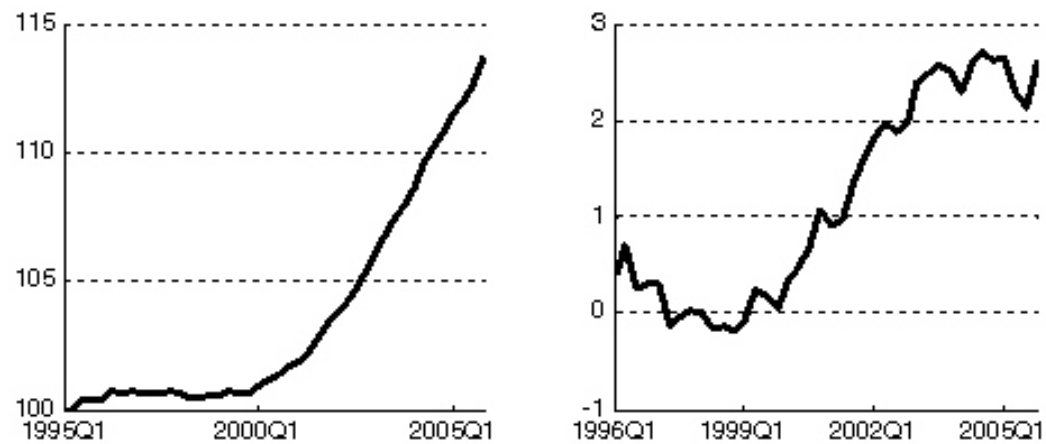

Source: Czech Statistical Office and own computations.

The measure of potential labour is computed using seasonally adjusted labour force data and estimates of the NAIRU. The left graph in Figure 4.2 shows the estimates of the NAIRU and the actual unemployment rate, while the right graph compares potential labour with the actual amount of the labour force (see footnote for the definition of the labour force).

Figure 4.2

The Components of Potential Labour (1995Q1-2005Q4)

Unemployment rate and the NAIRU

(in \%)

\section{Labour force and potential labour}

(thousands, s.a.)
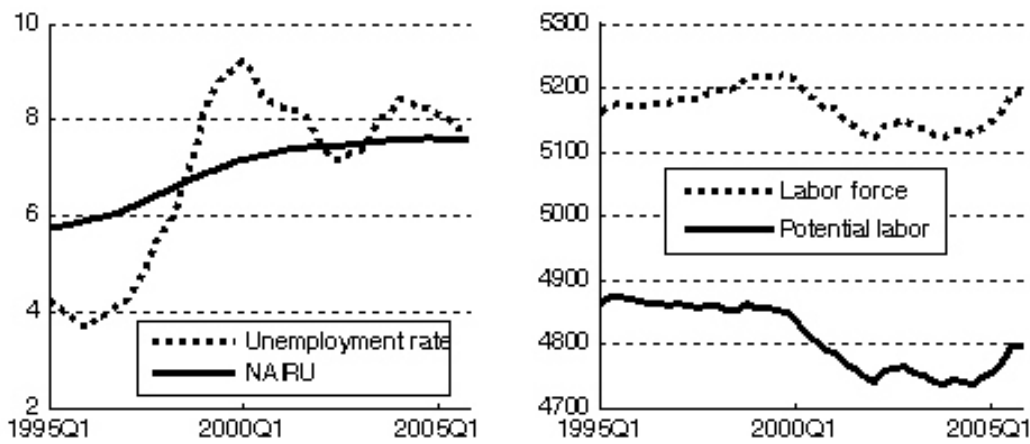

Source: Czech Statistical Office and own computations.

Our estimation shows that the NAIRU increased from roughly $5.5 \%$ in 1995 to $7.5 \%$ in 2002. The critical period in which we observe a rising NAIRU started in the last quarter of 1996 and ended in the first quarter of 1999. Since then, the NAIRU has remained roughly stable. The reported increase in the NAIRU has adversely affected potential labour and, given the stagnating or declining labour force, also the contribution of labour 
input to potential output growth. The reasons for the increase in the NAIRU can in general be attributed to worsening labour market efficiency. ${ }^{21}$

Figure 4.3 indicates that the volume of capital services rose over the studied period. On the right graph, however, it is visible that, after a period of still relatively high dynamics in 1996 and 1997, the annual growth rate of capital services flow gradually slowed, reaching a low in 2001. Subsequently, the annual growth rate remained around 3 per cent and accelerated from 2004 onwards.

Figure 4.3

Flow of Capital Services (1995Q1-2005Q4)

Quarterly flow of capital services

(bn CZK)

\section{Year-on-year growth of capital services (y-o-y growth in \%)}

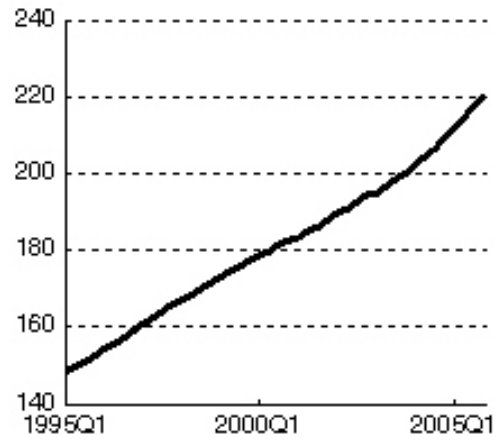

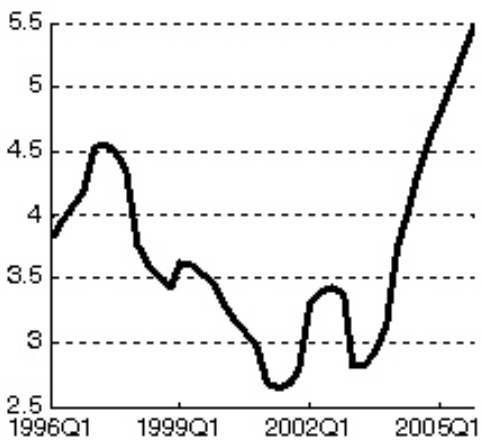

Source: Own calculations.

When interpreting the data on the year-on-year growth of capital services, it is necessary to keep in mind that capital services are derived from the existing stock of capital. The fast growth of capital services around 1997 reflects the investment boom of the years 1994-1996 (a reflection of the first wave of foreign direct investment in the Czech Republic). The rate of growth of capital services somewhat declined afterwards, but remained relatively solid despite the slump in economic activity in 1997 and 1998 and the generally weak investment activity in the rest of the 1990s.

In the second half of the 1990s, the investment activity of Czech companies consisted chiefly in infrastructure and restructuring investment, the reproduction of the capital stock concentrating mostly in the sectors of energy, telecommunications and production of motor vehicles. ${ }^{22}$ These sectors were also the main drivers of the aggregate growth in

21 In particular, we should mention counterproductive labour market regulations passed under political pressure from the trade unions (an increase in the minimum wage, a level of social benefits discouraging job search, excessive employment protection, etc.), low or even declining labour mobility and an increasing share of labour in GDP. Nevertheless, it is fair to say that not only increases in the NAIRU, but also a gradual decline in the labour force itself have contributed to the estimated gradual decrease in potential labour. See Hurník and Navrátil (2005a) for more comments on the increases in the NAIRU. Vašíček and Fukač (2000), Hájek and Bezděk (2001), Flek et al. (2001), Fukač (2003) and Bezděk, Dybczak and Krejdl (2003) also estimate the path of the NAIRU. All these estimates robustly show the NAIRU growing since 1996.

22 A description of investment activity in the late 1990s is provided by Hanzlová (2001). 
capital services. The second half of the 1990s also saw relatively dynamic investment in information and communications technology. ${ }^{23}$ The pick-up in capital services after 2003 is connected with the rise in investment activity since 2000 and related growth in the productive stock of capital.

Using equation (2.12), we finally calculate the path of potential output. Figure 4.4 (left-hand graph) displays potential output together with the evolution of real GDP. ${ }^{24}$ From the business cycle perspective, the analysis shows that the Czech economy experienced both phases of the business cycle over the period 1995-2000. Whereas the overheating reached its peak in 1996, the bottom was reached at the beginning of 1998 . The relatively quick swing from expansion towards recession can be viewed as evidence of relatively weak aggregate supply-side performance in the second half of the 1990s, as the supply side was largely unable to adjust to demand fluctuations.

In the period 2000-2005, the development of the Czech economy has been more stable. One can argue that, unlike the previous expansion period (1995-1996), the new expansion phase of the business cycle (starting in 2002) was accompanied by improvements in the functioning of the supply side, i.e. by a pick-up in potential output growth. Figure 4.4 (right-hand graph) shows that positive, although relatively low, potential output growth persisted until the end of 2000 , with a clear tendency to accelerate since the second half of 2001.

Figure 4.4

The Path of Potential Output (1995Q1-2005Q4)

GDP and potential output (bn CZK)

\section{Potential output (y-o-y growth in \%)}

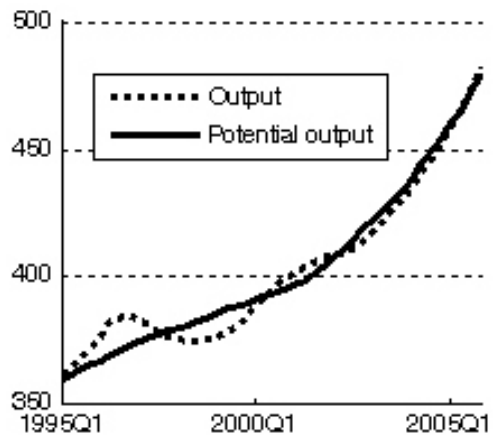

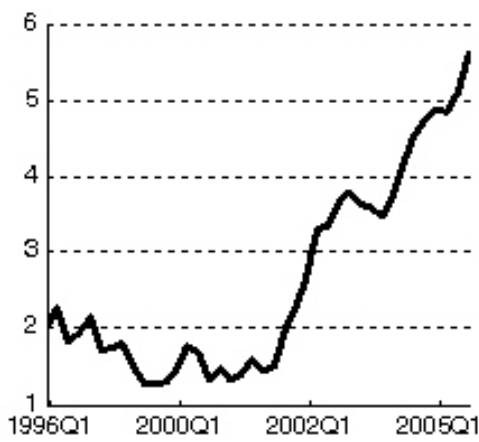

Source: Czech Statistical Office and own computations.

23 Data on gross fixed capital formation by commodity show very high dynamics of investment in radio, television and communication equipment and computer technology services. High growth in information and communication technology-related expenditures is also reported by Piatkowski (2003).

24 Hájek and Bezděk (2001) estimate that annual potential output grew on average by $1.5 \%$ during 1993-1999. Contrary to our approach, they use the Hodrick-Prescott filter to determine the time-varying NAIRU. In addition, Flek et al. (2001) use the exponential trend to estimate potential output growth, arriving at an estimated average growth rate during 1992-1999 close to 1\%. Hurník and Navrátil (2005b) report 2\% average potential output growth for 1996-2003 using a similar methodology for the NAIRU estimation, but without the concept of capital services. 
The above-described path of potential output can be further illustrated by the evolution of its determinants. Table 4.1 summarises the contributions of trend total factor productivity, potential labour and capital services to potential output growth.

Table 4.1

Decomposition of Potential Output Growth (average of q-o-q annualised growth)

\begin{tabular}{|c|c|c|c|c|}
\hline \multirow{2}{*}{\multicolumn{2}{|c|}{$\begin{array}{c}\text { Potential output } \\
(\%)\end{array}$}} & \multicolumn{3}{|c|}{ Contribution to growth } \\
\hline & & \multirow{2}{*}{ 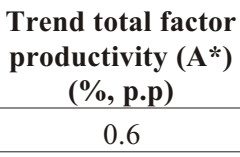 } & \multirow{2}{*}{$\begin{array}{c}\begin{array}{c}\text { Potential labour } \\
\left(\mathbf{L}^{*}\right) \\
\text { (p.p.) }\end{array} \\
0.2 \\
\end{array}$} & \multirow{2}{*}{$\begin{array}{c}\text { Capital services } \\
(\boldsymbol{K}) \\
(\text { p.p. })\end{array}$} \\
\hline 1995 & 2.2 & & & \\
\hline 1996 & 2.0 & 0.3 & -0.1 & 1.7 \\
\hline 1997 & 1.8 & 0.0 & 0.0 & 1.8 \\
\hline 1998 & 1.3 & -0.2 & 0.0 & 1.4 \\
\hline 1999 & 1.3 & 0.0 & -0.2 & 1.4 \\
\hline 2000 & 1.6 & 1.1 & -0.7 & 1.2 \\
\hline 2001 & 2.2 & 1.6 & -0.5 & 1.2 \\
\hline 2002 & 3.6 & 2.0 & 0.2 & 1.4 \\
\hline 2003 & 3.4 & 2.5 & -0.4 & 1.3 \\
\hline 2004 & 4.6 & 2.6 & 0.1 & 1.9 \\
\hline 2005 & 5.1 & 2.2 & 0.6 & 2.2 \\
\hline 1995-2005 & 2.7 & 1.2 & -0.1 & 1.6 \\
\hline
\end{tabular}

Source: Czech Statistical Office and own computations.

The main driver of the relatively sluggish potential output growth in the second half of the 1990s was the flow of capital services. The contribution of potential labour was roughly zero due to increasing NAIRU and declining labour force, and the contribution of the trend total factor productivity was similar after 1995. Although the capital input was growing, the zero growth of the trend total factor productivity at the same time signals that the investment activity was probably far from effective. As the potential output growth was fully dependent on the growth of just one input, capital services, this can hardly be viewed as consistent with an efficiently functioning supply side.

Many capital resources in that period were never used for their initially declared investment purposes, as they turned out to be unrealistic. Consequently, the real values of investment were revised to lower levels. A slowdown in the contribution of capital services, along with negative growth of the trend total factor productivity, then caused a slowdown in potential output growth to almost $1 \%$ in 1998 . This may support the idea of rather ineffective investment in the preceding years.

After 2001, the annual average contribution of the trend total factor productivity to potential output growth exceeded $2 \%$. This, along with accelerating capital services and a positive contribution of labour in the last two years, gradually raised the annual growth of potential output to $5 \%$ in 2005 . Such an increase in potential output growth, together with the growth in both capital services and the trend total factor productivity, signals more efficient use of resources and hence, improvements in supply-side performance.

In our view, this can be attributed to gradually increasing efficiency of investment since the very end of the 1990s, which coincides with the acceleration of FDI inflows. 
The positive and increasing growth rates of the trend total factor productivity during 2000-2005 could be taken as support for that. One can infer that the FDI has been used efficiently and has contributed to increases in productivity.

Despite the improvements in the functioning of the supply side reported above, labour market efficiency in 2005 still was an issue, since the NAIRU remained stable at around $7.5 \%$ representing a rather high trade-off between inflation and unemployment.

Our analysis naturally raises the question of what the potential output would have been had the supply side been working more efficiently. Answers to such questions can be obtained from potential output growth simulations.

\section{Simulations}

Simulations can be used to identify the relative importance of particular factors of potential output growth. To put differently, potential output simulations help us to classify the impact of different market inefficiencies. For instance, one can address the question of what the potential output would have been had the NAIRU remained stable at 5.5\%. In order to address these questions, we carry out several simulations using arbitrary assumptions for the development of particular factors. To do so, we substitute into the production function hypothetical values for the relevant variables instead of the originally computed data.

We run three simulations (NAIRU, Capital and Trend total factor productivity - see Figure 5.1). Within the NAIRU simulation, we assume stability of the NAIRU at 5.5\%, which was the NAIRU level in 1996. This should quantify the loss stemming from absent (or inefficient) structural labour market policies and flexible labour market institutions that stimulate potential output growth. In the capital simulation, we assume that the annual growth in capital services has remained at 5\% since 1996, i.e. assuming that the drop in investment activity at the end of the 1990s was avoided. Finally, in the trend total factor productivity simulation, we assume stable annual growth of the trend total factor productivity of $1.8 \%$, i.e. a substantially higher degree of technological innovation and better productive use of factor inputs (this is the average annual growth of the trend total factor productivity in Germany between 1963-1999; Lehman Brothers, 2000).

Figure 5.1

Simulations of Potential Output Development (1995Q1-2005Q4)

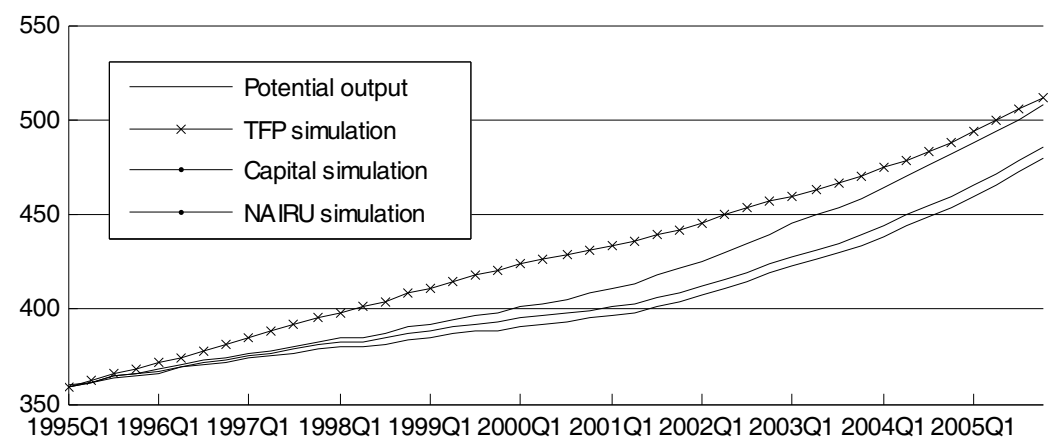

Source: Czech Statistical Office and own computations. 
As can be seen in Figure 5.1, the positive impact of a lower NAIRU level on potential output is not too marked - at the end of 2005 the simulated value of the NAIRU would have increased the potential output level by $1.3 \%$ compared to the baseline scenario. This would imply an average annual increase in potential output growth over the analysed period of only 0.1 p.p.

Furthermore, Figure 5.1 shows that the difference between the baseline scenario and the capital services simulation has become substantial since 2000, and at the end of 2005 the difference in potential output levels between the simulation and the baseline scenario is around $5.9 \%$. This represents an average annual increase in potential output growth of 0.6 p.p. over 1995-2005. Thus it appears that the observed drop in capital stock formation in the late 1990s constrained potential output growth more substantially than the rise in the NAIRU.

The TFP simulation implies that the level of potential output would have been $6.6 \%$ higher at the end of 2005 compared to the baseline scenario. In other words, the simulated growth of the trend total factor productivity would imply an average annual increase in potential output growth of 0.7 p.p. in the period covered by our analysis. Such an impact of the trend total factor productivity reflects the crucial role of efficient resource allocation and utilisation for potential output growth. It could even be argued that the difference between the trend total factor productivity in baseline and simulation chiefly reflects the extent of the imperfections in supply-side functioning that the Czech economy was facing, especially during the 1990 s. $^{25}$

\section{Conclusion}

As established by our analysis, the Czech economy experienced relatively slow annual average growth in potential output of around $2.7 \%$ during the years $1995-2005$. This average number, however, masks two rather different periods. While the average annual potential output growth reached only $1.7 \%$ during the period 1995-2000, the period from 2001 onwards is characterised by a potential output growth rate of around $3.8 \%$, with a tendency to accelerate. The first period was, in addition, accompanied by significant fluctuations in current output relative to the estimated potential, whereas in the second period, the development of current output has been quite smooth with respect to the estimated potential. Had the economic recovery starting in 2001 not been accompanied by a pick-up in potential output growth, the economy would have had to undergo another painful adjustment. An important development was the gradual improvement in the structure of growth which reached all considered production factors. The acceleration in total factor productivity growth since 2000 signalizes increasing efficiency of investment. The contribution of labour became positive at the end of the analysed period. The macroeconomic evidence thus suggests a remarkable improvement in supply-side functioning and a rather broad-based potential output growth.

25 Both the capital and NAIRU simulations do not assume any impact on the trend total factor productivity. For instance, in the case of the NAIRU, a policy could be arranged which would lead to a more skilled labour force. This would be reflected in lower unemployment, but also in higher productivity of the "better skilled" labour. Our simulation, however, reflects just the decline in unemployment, leaving the trend total factor productivity unchanged. 
Simulations of various paths of potential output growth show that a low contribution of total factor productivity can be seen as the main reason for the slow potential output growth during the second half of the 1990s. The future prospects for potential output growth critically depend on the stability of total factor productivity growth. Should the recent improvement in total factor productivity and the contribution of capital services last over the longer run, the future potential output growth can be expected to maintain its current magnitude of 5-6\%. Further pick-up in potential output growth could stem from a decrease in the NAIRU. This, however, requires an adequate set of labour market legislation and policy measures that would lead to improvements in labour market efficiency.

\section{References}

Barro, R.J. (1998), "Notes on Growth Accounting." NBER Working Paper No. 6654.

Barro, R., Sala-i-Martin, X. (1995), Economic Growth. $2^{\text {nd }}$ Ed. Cambridge, Mass : MIT Press.

Baxter, M., King, R. (1995), "Measuring Business Cycles Approximate Band-Pass Filters for Economic Time Series." NBER Working Paper No. 5022.

Beffy, P.-O., Ollivaud, P., Richardson, P., Sédillot F. (2006), "New OECD Methods for Supply-side and Medium-term Assessment: A Capital Services Approach", OECD Economics Department Working Paper No. 482.

Beneš, J., N'Diaye, P. (2004), "A Multivariate Filter for Measuring Potential Output and the NAIRU: Application to the Czech Republic." IMF Working Paper No. 45.

Bezděk, V., Dybczak, K., Krejdl, A. (2003), "Czech Fiscal Policy: Introductory Analysis.” Working Paper No. 7. Czech National Bank, Prague.

Bosworth, B.P., Collins, F.M. (2003), "The Empirics of Growth: An Update." Brookings Papers on Economic Activity, 2, pp. 113-179.

Christiano, L., Fitzgerald, J. (1999), “The Band-Pass Filter.” NBER Working Paper No. 7257.

Denis, C., Grenouilleau, D., Mc Morrow, K., Röger, W. (2006), "Calculating Potential Growth Rates and Output Gaps - A Revised Production Function Approach," European Economy Economic Papers, No. 247.

Flek, V. et al. (2001), "Supply-Side Performance and Structure" (in Czech). Working Paper No. 27. Czech National Bank, Monetary Department, Prague.

Fukač, M. (2003), "Non-Accelerating Inflation Rate of Unemployment." Mimeo. CERGE-EI, Prague. http://home.cerge-ei.cz/fukac.

Giorno, C., Richardson, P., Roseveare, D., van den Noord, P. (1995), "Estimating Potential Output, Output Gaps and Structural Budget Balances," OECD Working Paper No. 152.

Gomme, P., Rupert, P. (2004), "Measuring Labor's Share of Income," Federal Reserve Bank of Cleveland Policy Discussion Paper, Number 7.

Griffin, N., Odaki, K. (2006), "Reallocation and Productivity Growth in Japan: Revisiting the Lost Decade of the 1990s," Congressional Budget Office Paper, Washington, DC.

Grossman, G.M., Helpman, E. (1991), Innovation and Growth in the Global Economy. Cambridge, Mass : MIT Press.

Hájková, D. (2006), "The Capital Input into Czech Production: An Experimental Measure of Capital Services," CERGE-EI Discussion Paper 168.

Hájková, D., Hurník, J. (2007), "Cobb-Douglas Production Function: The Case of a Converging Economy." Czech Journal of Economics and Finance, (9-10), pp. 465-476.

Hájek, M. (2006), "Zdroje růstu, souhrnná produktivita faktorů a struktura v České republice." Politická ekonomie, (2), pp. 170-188.

Hájek, M., Bezděk, V. (2001), "Estimate of the Potential Product and the Output Gap in the Czech Republic" (in Czech). Working Paper No. 26. Czech National Bank, Monetary Department, Prague.

Hanzlová, D. (2001), "Analýza vývoje hrubých hmotných investic v průběhu 90. let." ("Analysis of the Development of Gross Fixed Investment in the 1990s"), Czech Statistical Office.

Hamilton, J.D. (1994), Time Series Analysis. Princeton : Princeton University Press. 
Hurník, J., Navrátil, D. (2005a), "Labor Market Performance and Macroeconomic Policy: The Time Varying NAIRU in the Czech Republic." Czech Journal of Economics and Finance, (1-2), pp. 25-40.

Hurník, J., Navrátil, D. (2005b), "Potential Output in the Czech Republic: A Production Function Approach." Prague Economic Papers, (3), pp. 253-266.

Krueger, A.B. (1999), "Measuring Labor's Share," NBER Working Paper No. 7006.

Lehman Brothers (2000), "Euro 2000: They Think It's All Over..." Structural Economics Research Papers No. 1, London.

OECD (2001), Measuring Capital - OECD Manual. Paris.

Piatkowski, M. (2003), "Does ICT Investment Matter for Growth and Labor Productivity in Transition Economies?" TIGER Working Paper Series, No. 47.

Romer, D. (2002), Advanced Macroeconomics. $2^{\text {nd }}$ Ed. New York: McGraw-Hill.

Romer, P.M. (1990), “Endogenous Technological Change.” Journal of Political Economy, 98, pp. 71-102.

Scacciavillani, F., Swagel, P. (1999), "Measures of Potential Output: An Application to Israel." IMF Working Paper No. 96.

Schreyer, P. (2004), "Measuring MFP when Rates of Return are Exogenous." Paper presented at the SSHRC International Conference on Index Number Theory and the Measurement of Prices and Productivity. Vancouver, June 30 - July 3, 2004.

Schreyer, P., Bignon, E., Dupont, J. (2003), "OECD Capital Services Estimates: Methodology and First Results." Statistics Directorate Working Paper No. 6. Paris. 